\title{
Life Cycle of Marine Leech from Cultured “Cantik” Hybrid Grouper (Ephinephelus sp.) and Their Susceptibility Against Chemicals
}

\author{
Murwantoko $^{1 *)}$, Sri Laksono Condro Negoro ${ }^{1}$, Alim Isnansetyo ${ }^{1}$, and Zafran ${ }^{2}$ \\ ${ }^{l}$ Department of Fisheries, Faculty of Agriculture Universitas Gadjah Mada, Yogyakarta \\ ${ }^{2}$ Institute For Mariculture Research and Fisheries Extension, Gondol Buleleng Bali \\ ${ }^{*}$ Email: murwantoko@ugm.ac.id
}

\begin{abstract}
Murwantoko, Sri Laksono Condro Negoro, Alim Isnansetyo, and Zafran. 2017. Life Cycle of Marine Leech from Cultured Cantik Hybrid Grouper (Ephinephelus sp.) and Their Susceptibility Against Chemicals. Aquacultura Indonesiana, 18 (2): 72-76. Grouper is an important fish species due to high price both in domestic and international market. Several hybrid groupers have been released and can be accepted by farmers. A major production constraint in grouper culture is mortality due to disease. Leech is an ectoparasite for grouper which may cause significant loss, so that controlling this parasite is important as one of aquaculture management tools. The objectives of this study was to know the life cycle of leech on hybrid grouper and determine the efficacy of chemicals to kill leech under laboratory condition with diffferent dossage and immersing time. Life cycle was observed by reared an adult leech, counted the fecundity and observed the development of eggs until reach adult stages. The efficacy of formalin, albendazole, oxfendazole, levamisole, $\mathrm{H}_{2} \mathrm{O}_{2}, \mathrm{CuSO}_{4}$, ivermectin, vermizyn and freshwater on several concentration were assessed to kill adult leeches. All chemicals tested (except for freshwater), are dissolved in saline water salinity of $35 \mathrm{ppt}$ at concentrations of 1000, 500, 250, 125 and $62.5 \mathrm{ppm}$. During 3 days of rearing, the adult leech could deposit of 11 eggs in average, with $600 \mu \mathrm{m}-800 \mu \mathrm{m}$ in diameter. Twelve days were needed for the new egg inside the cocoon to hatch and develop into larvae under $24-25^{\circ} \mathrm{C}$ at $34 \mathrm{ppt}$ of salinity. It took another 9 days for the leeches larvae to grow reach mature stage. Five chemicals were able to kill leeches, which were fresh water, formalin, levamisol, ivermectin, and CuSO4. Treatment by exposure leech to freshwater for 30 minutes shows effective to kill leech. Treatment with formalin with a concentration of $500 \mathrm{ppm}$ able to kill leech after 30 minutes immersion, and at concentration of $250 \mathrm{ppm}$ able to kill leech after 1 hour immersion.
\end{abstract}

Keywords: Alkaloid isolation and identification; Immunostimulant; Protein profile; Phagocytic activity; Vibrio harveyi

\section{Introduction}

Several species of grouper have been cultured and become important fish commodity in Indonesia. Hatcheries have produced tiger grouper (Ephinephelus fuscoguttatus) and mouse grouper (Cromileptes altivelis) juveniles to fulfill grouper demands. The hybrid groupers also haven been produced in hatcheries. Cantang Grouper (Epinephelus sp.) is result of crossbreed between female tiger grouper and male giant grouper (E. lanceolatus). The crossbreed between the female tiger grouper and the male brownmarbled grouper (E. microdon) named the "cantik" grouper (Ismi et al., 2013). One of the problems on the aquaculture is the emergence of diseases. Emerging disease epizootics frequently cause substantial, often explosive and losses among populations of fish and shrimp, resulting in large economic losses in commercial aquaculture and threats to valuable stocks of wild aquatic animals (Walker et al., 2010). Koesharyani et al. (2001) have compiled the viral, bacterial, parasitic and noninfectious diseases in grouper. The hirudinea infection on grouper is one problem for parasitic diseases.

Hirudinea is a symmetrical bilateral leeches or worms with more or less having a uniform metameric body. The Piscicolidae family has characteristics of having a symmetrical, flattened cylinder body, having an anterior suction and a posterior suction. Species of the family Pisciolidae are often parasitic sea water fish, such as Pterobdella amara, Aestabdella leiostomi, Piscicola spp., and Zeylanicobdela arugamensis (Chandra, 1991). Grouper having infected leeches on its skin, will rub the body on objects around so it causing injuries that can cause secondary infection (Johnny and Roza, 2006). Beside as a fish parasit, the importance of leeches is as vectors of pathogens (Burreson, 1995). It would be appropriate to look at possible 
viruses and blood parasites associated with heavy infestation of leech in grouper (Cruz-Lacierda $e t$ al., 2000).

Several methods to control leech infection have been suggested. Koesharyani et al. (2001) suggested with bathing in 200-250 ppm formalin for 1 hour followed by bathing in antibiotic for 1 $2 \mathrm{~h}$ to prevent secondary bacterial infection. Marine leech can be effectively controlled using $50 \mathrm{ppm}$ formalin bath treatment for 1 hour (Lacierda et al., 2000). Groupers have been cultured using floating net cages in Sumberkima Buleleng with the most popular cultured species is "cantik" hybrid grouper. An outbreak of leeches has been reported in this bay on August 2016. In this study we determined life cycle and evaluated efficacy of chemicals, which were Albendazole (Vermic), Oxfendazole (VERM-O,), Vermyzin (SBK), Ivermectin (Ivocip paste), and Levamisole (Askamex), Formalin, $\mathrm{CuSO}_{4}$, and $\mathrm{H}_{2} \mathrm{O}_{2}$ to kill leeches under laboratory condition.

\section{Materials and Methods}

\section{Leeches Sampling}

Sampling was conducted on "cantik" hybrid grouper farms in Pegametan Bay Sumberkima Buleleng on September-October 2016. Fishes were collected from cages using scope net. Leeches were observed from fishes with naked eyes. The leeches were sampled in alive and collected in containers with seawater and transfered to at Pathology Laboratory, Gondol Institute For Mariculture Research and Fisheries Extension.

\section{Parasite Lifecycle Observation}

The lifecycle of parasite was observed following method of Kua et al. (2010) that conducted to determine fecundity, development of egg until hatch, and growth from leech larvae to adult. For fecundity test, 27 adult leeches were placed on petri dishes containing sea water with salinity of 34 ppt at $24-25{ }^{\circ} \mathrm{C}$. The eggs production was observed every 24 hours. For determination of eggs development, eggs were incubated on seawater in petri dishes, then five eggs were sampled daily and observed under microscope. The growth leech observation was done by infecting hatched leech larvae into 5 fishes of "cantik" grouper with $11 \mathrm{~cm}-14 \mathrm{~cm}$ in length. Fishes were reared on 5 liters seawater with aeration and water change rate every 3 days.
After reach adult stage, the leeches were removed from fish and reared in petri dishes containing seawater to observe the egg production.

\section{Chemical efficacy}

Eight chemicals were evaluated for their efficacy to kill leeches. The chemicals used were Albendazole (Vermic), Oxfendazole (VERM-O,), Vermyzin (SBK), Ivermectin (Ivocip paste), and Levamisole (Askamex), Formalin, $\mathrm{CuSO}_{4}$, and $\mathrm{H}_{2} \mathrm{O}_{2}$. All chemicals tested (except for freshwater) are dissolved in saline water salinity of $35 \mathrm{ppt}$ at concentrations of 1000, 500, 250, 125 and $62.5 \mathrm{ppm}$. Each concentration of chemical solution was put in petri dish at $25^{\circ} \mathrm{C}$. The 40 adult leeches were put into every experimental unit and observed every 30 minutes for 4 hours. For each observation, 5 leeches were moved into petri dishes containing sea water. Leech that has not movement activity and do not show any signs of life indicated that leech was dead.

\section{Results}

\section{Eggs development}

The leeches can be seen as black or brown leeches attached on body surface. Some fishes showing hemorrhagic on their body surfaces. The result showed that 27 adult leeches produced 294 eggs within 72 hours, or in average one leech produced 11 eggs. This egg has a flat circular shape with a diameter of $600 \mu \mathrm{m}-800$ $\mu \mathrm{m}$ and a thick egg shell. Under incubation on 25 ppt salinity at $24-25{ }^{\circ} \mathrm{C}$, the development of larvae is shown in Figure 1.

The egg development begins from the morula stage on day 1 (A). On the second day shows the early blastula phase (B) ending on the 4th day (D). The 5th day shows the early gastrula phase (E) then the gastrula phase lasts until day to $8(\mathrm{H})$. The $9^{\text {th }}$ day is the initial phase of the embryo (I) formation until all the organs are clearly established until day $11(\mathrm{~K})$. On the $12^{\text {th }}$ day, the embryo hatches into the leech (L) larvae.

\section{Leech development}

The newly hatched leech larva has a transparent color with around $1 \mathrm{~mm}$ in length. The larva can swim and move around using its sucker. The development of leech larvae is shown in Figure 2. 


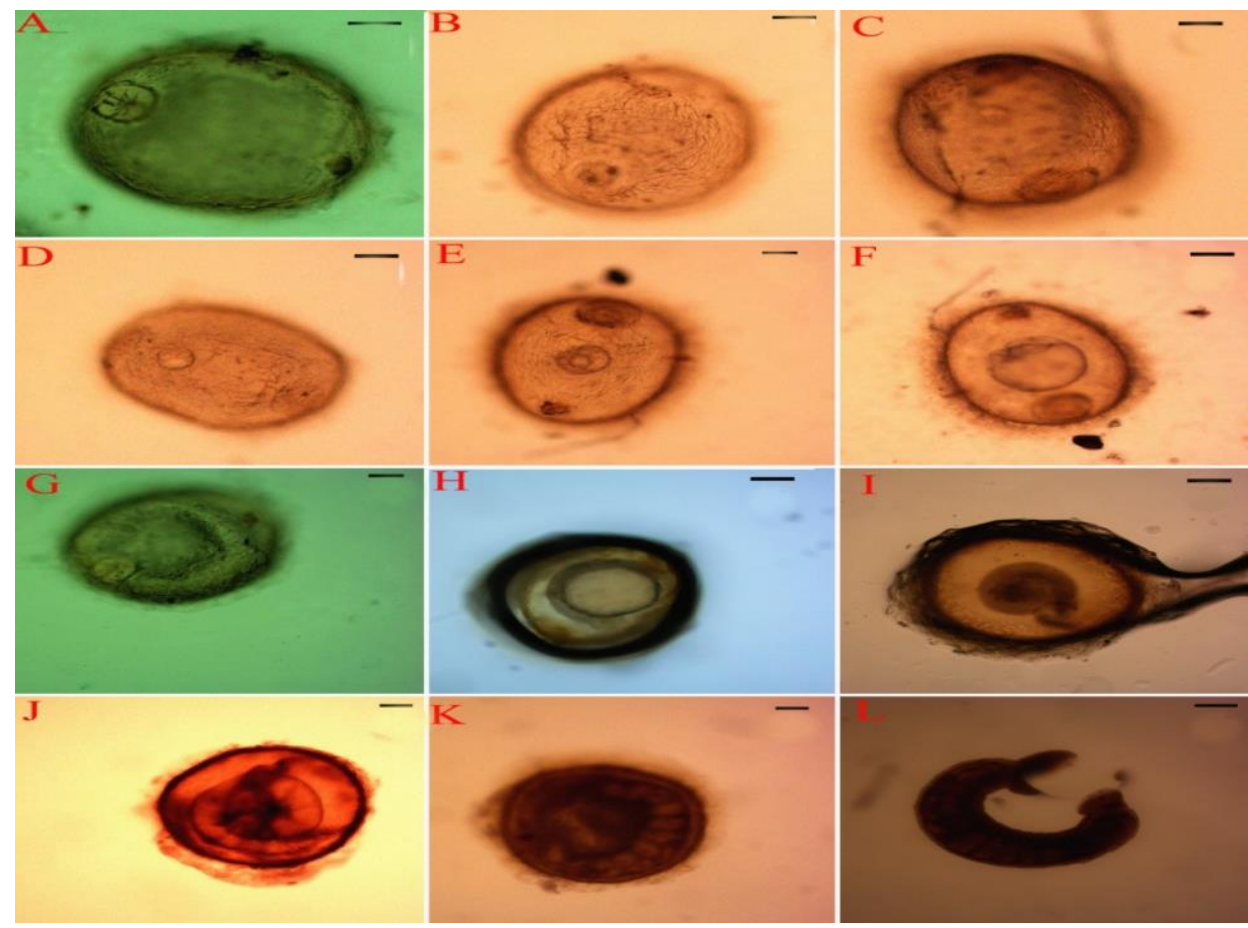

Figure 1. Development of leech egg to larvae (A: day 1; B: day 2; C: day 3; D: day 4; E: day 5; F: day 6; G: day 7; H: day 8; I: day 9; J: day 10; K: day 11; L: day: 12; - =100 $\mu \mathrm{m})$

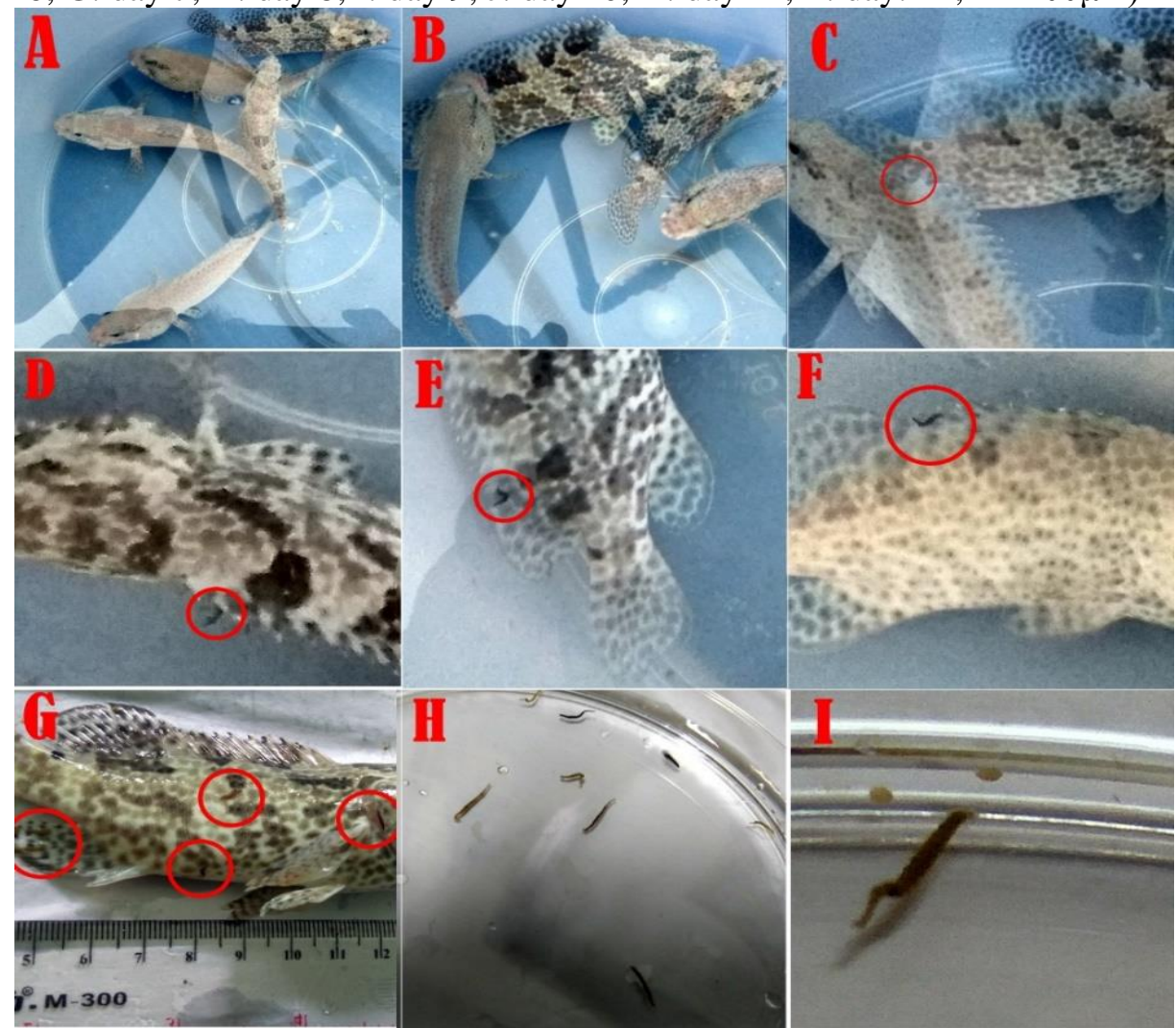

Figure 2. Growth of leech (A: day 1; B: day 2; C: day 4; D: day 6; E: day 8; F: day 9; G: harvest leech day $9 ; \mathrm{H}$ : leech, I: leech produced eggs)

On day 1 and day 2, leech larvae still not visible because the size is still small. On day 4 (C) the larvae has grown and can be observed. On day 6 (D) leech has been seen infecting on the fins, body surface and tail. On the day 9 (F) leech has reached the size of $10 \mathrm{~mm}$ until $15 \mathrm{~mm}$, then collected $(\mathrm{G})$. The collected leeches were placed in a petri dish containing sea water $(\mathrm{H})$ and leech gives eggs 4 hours later (I). So this species of newly hatched larvae to adulthood and producing eggs takes 9-10 days, so the total of the entire life cycle from egg to adult and produce eggs is about 21-22 days. 


\section{Efficacy of chemicals for killing leech}

The efficacy of chemicals test showed that chemicals have different effectiveness in killing leeches, depending on the type of chemicals and their concentration (Table 1). Only 5 chemicals were able to kill leeches, which were fresh water, formalin, levamisol, ivermectin, and CuSO4. The use of fresh water for 30 minutes can kill the leech. The use of ivermectin, CuSO4, levamisole, and Formalin at a concentration of $62.5 \mathrm{ppm}$ was able to kill the leech after immersion for 30 minutes, 60 minutes, 150 minutes and 150 minutes, respectively. Ivermectin at a concentration of 10 ppm can kill within 180 minutes. Formalin with a dose of $500 \mathrm{ppm}$ and $250 \mathrm{ppm}$ able to kill leech after immersion for 30 minutes and 1 hour respectively. While albendazole, vermyzin, oxfendazole and $\mathrm{H}_{2} \mathrm{O}_{2}$ at concentration $1000 \mathrm{ppm}$ and for 4 hours of immersion could not kill the leech.

Table 1 Eficacy of chemicals on killing leech.

\begin{tabular}{|c|c|c|c|c|c|c|c|c|c|}
\hline Chemicals & $\begin{array}{c}\text { Concen-tration } \\
(\mathrm{ppm})\end{array}$ & $\begin{array}{c}30 \\
\mathrm{~min}\end{array}$ & $\begin{array}{c}60 \\
\text { min }\end{array}$ & $\begin{array}{c}90 \\
\mathrm{mn}\end{array}$ & $\begin{array}{l}120 \\
\min \end{array}$ & $\begin{array}{l}150 \\
\min \end{array}$ & $\begin{array}{l}180 \\
\min \end{array}$ & $\begin{array}{l}210 \\
\min \end{array}$ & $\begin{array}{l}240 \\
\min \end{array}$ \\
\hline \multirow[t]{5}{*}{ Formalin } & 1000 & - & - & - & - & - & - & - & - \\
\hline & 500 & - & - & - & - & - & - & - & - \\
\hline & 250 & + & - & - & - & - & - & - & - \\
\hline & 125 & + & + & - & - & - & - & - & - \\
\hline & 62,2 & + & + & + & + & - & - & - & - \\
\hline \multirow[t]{2}{*}{ Albendazole } & 1000 & + & + & + & + & + & + & + & + \\
\hline & 500 & + & + & + & + & + & + & + & + \\
\hline \multirow[t]{5}{*}{ Levamisole } & 1000 & - & - & - & - & - & - & - & - \\
\hline & 500 & + & - & - & - & - & - & - & - \\
\hline & 250 & + & + & - & - & - & - & - & - \\
\hline & 125 & + & + & + & - & - & - & - & - \\
\hline & 62,2 & + & + & + & + & - & - & - & - \\
\hline \multirow[t]{2}{*}{ Vermyzin } & 1000 & + & + & + & + & + & + & + & + \\
\hline & 500 & + & + & + & + & + & + & + & + \\
\hline \multirow[t]{2}{*}{ Oxfendazole } & 1000 & + & + & + & + & + & + & + & + \\
\hline & 500 & + & + & + & + & + & + & + & + \\
\hline \multirow[t]{6}{*}{ Ivermectin } & 1000 & - & - & - & - & - & - & - & - \\
\hline & 500 & - & - & - & - & - & - & - & - \\
\hline & 250 & - & - & - & - & - & - & - & - \\
\hline & 125 & - & - & - & - & - & - & - & - \\
\hline & 62,2 & - & - & - & - & - & - & - & - \\
\hline & 10 & + & + & + & + & + & - & - & - \\
\hline \multirow[t]{2}{*}{$\mathrm{H}_{2} \mathrm{O}_{2}$} & 1000 & + & + & + & + & + & + & + & + \\
\hline & 500 & + & + & + & + & + & + & + & + \\
\hline \multirow[t]{6}{*}{$\mathrm{CuSO}_{4}$} & 1000 & - & - & - & - & - & - & - & - \\
\hline & 500 & - & - & - & - & - & - & - & - \\
\hline & 250 & + & - & - & - & - & - & - & - \\
\hline & 125 & + & - & - & - & - & - & - & - \\
\hline & 62,2 & + & - & - & - & - & - & - & - \\
\hline & 10 & + & + & - & - & - & - & - & - \\
\hline Freshwater & 0 & - & - & - & - & - & - & - & - \\
\hline
\end{tabular}

Note: (+) indicate leech still alive,(-) indicated leech already dead at indicated concentration and duration of treatment.

\section{Discussion}

The leeches can be seen visually attached to the fins, tail, body, operculum, mouth and eyes of fishes. Some fishes showing hemorrhagic on their body surfaces. This is consistent with the statements of Johnny and Roza (2006) which suggest a parasitic infection leeches are found in the external part of the fish and causes hemorrhages so that it can lead to secondary bacterial infection. According to Ravi and Yahaya (2016), the most frequent effect of leech infection in fish are local bleeding and ulceration in fish tissues.

The result of this study showed that leech fecundity was 11eggs/animal. This fecundity is a little bit higher than Kua et al. (2010) showed fecundity is 9 eggs with record during research using water temperature of $27^{\circ} \mathrm{C}$ and salinity 28 ppt. In the study of egg fertility, a single juvenile leech was placed in a beaker can produced eggs after day 11 and $34.2 \%$ of them were hatched which indicating that single leech could 
reproduce fertilized egg capable of hatching (Kua et al. 2010)

Leech life cycle in this study was \pm 21 days, with time from eggs to hatch for 12 days and from newly hatched larvae until adult capable produce eggs for 9 days in temperatures $24-25{ }^{\circ} \mathrm{C}$ with salinity $34 \mathrm{ppt}$. Meanwhile, according to Kua et al. (2010), the life cycle of Zeylanicobdella arugamensis takes about 16 days with time from eggs to hatching for 7 days and the development of larvae into adulthood until it can spawn again for 9 days with $28 \mathrm{ppt}$ water salinity and $27^{\circ} \mathrm{C}$ water temperature. According to Ravi and Yahaya (2016), the development of eggs on Zeylanicobdella arugamensis is affected by temperature during the hatching time.

The outbreak of leech in all farms of groupers may due to the quick life cycle and fast breeding. Then the first infection case in the Pegametan bay area caused by the flow of currents or other fish. This is in accordance with CruzLacierda et al. (2000), that the leech infecting may caused by fish carrier, through trash feed and carried by the current flow. The adult leeche produced eegs and put their its eggs in substrate subtrates such as nets, drums, wood and stones around the farm.

Five chemicals showed their ability to kill leeches, namely freshwater, formalin, levamisole, $\mathrm{CuSO} 4$ and ivermectin. Fresh water can kill the leech within 30 minutes. This results is different with observation of Cruz-Lacierda et al. (2000) that all treated leeches died after $1 \mathrm{~h}$ exposure to freshwater. Formalin with a concentration of 500 ppm able to kill leech after 30 minutes immersion, and at concentration of $250 \mathrm{ppm}$ able to kill leech after 1 hour immersion. This lethal concentration is higher than that of the CruzLacierda et al. (2000) study which obtained formalin concentrations of 50-200 ppm effective for killing leeches. In this study adult leeches were used. So it still important to know about the efficacy of this material in other stadia, for example in eggs. Eggs are very resistant to chemical treatment (Burreson, 1995).

\section{Conclussions}

Five chemicals were able to kill leeches (Zeylanicobdela arugamensis), which were fresh water, formalin, levamisol, ivermectin, and CuSO4. Treatment by exposure leech to freshwater for 30 minutes shows effective to kill leech. Formalin with a concentration of $500 \mathrm{ppm}$ able to kill leech after 30 minutes immersion, and at concentration of $250 \mathrm{ppm}$ able to kill leech after 1 hour immersion.

\section{Acknowledgment}

The authors would like to give high appreciation to the farmers, who permitted to conduct research and many technical supports.

\section{References}

Burreson, E.M., 1995. Phylum Annelida: Hirudinea as vectors and disease agents. In: Woo, P.T.K. (Ed). Fish Diseases and Disorders: Vol. 1. Protozoan and Metazoan Infections. CAB International, UK, pp. 599-629.

Chandra, M. 1991. A check-list of leeches of India. Rec.Zool.Surv.India., 80:265-290.

Cruz-Lacierda, E.R., J.D. Toledo, J.D. Tan-Fermin, and E.M. Burreson. 2000. Marine leech (Zeylanicobdella arugamensis) infestation on cultured orange-spotted grouper, Epinephelus coiodes. Aquaculture, 185:191-196. http:// www.sciencedirect.com/science/article/pii/S004 4848699003567

Ismi, S., Y.N. Asih, and D. Kusumawati. 2014. Improvement of Seed Production and Quality of Grouper by Hybridization Program. Jurnal Oseanologi Indonesia 1:1-5. http://journal. ipb.ac.id/index.php/isoi/article/view/8601

Johnny, F., and D. Roza. 2006. Infeksi Parasit Hirudinea pada Induk Ikan Kerapu Lumpur, Epinephelus bleekeri dan Kerapu Batik, Epinephelus polyphekadion Serta Upaya Penanggulangannya. BBPBL Gondol. Bali.

Koesharyani, I., D. Roza, K. Mahardika, F. Johnny, Zafran, and K. Yuasa. 2001. Marine Fish and Crustaceans Diseases in Indonesia $I n: \mathrm{K}$. Sugama, K. Hatai and T. Nakai (Eds). Manual for Fish Diseases Diagnosis. Gondol Research Station for Coastal Fisheries, CRIFI and Japan International Cooperation Agency, $44 \mathrm{p}$.

Kua, B.C., M.A. Azmi, and N.K.A. Hamid. 2010. Life cycle of the marine leech (Zeylanicobdella arugamensis) isolated from sea bass (Lates calcarifer) under laboratory conditions. Aquaculture, 302:153-157. http://www. sciencedirect.com/science/article/pii/S00448486 10001389

Ravi R. and Z.S. Yahaya. 2016. Zeylanicobdella arugamensis, the marine leech from cultured crimson snapper (lutjanus erythropterus), jerejak island, penang, malaysia. Asian Pacific Journal of Tropical Biomedicine, 7(5): 1-5. http://www.science direct.com/science/article/pii/S2221169116300995

Walker, P.J. and J.R. Winton 2010. Emerging viral diseases of fish and shrimp. Vet.Res., 41(6):51. https://www.ncbi.nlm.nih.gov/pmc/ articles/PMC2878170/ 